\title{
Utilization of algal and bacterial extracellular polymeric secretions (EPS) by the deposit-feeding brittlestar Amphipholis gracillima (Echinodermata)
}

\author{
D. L. Hoskins ${ }^{1, *}$, S. E. Stancyk ${ }^{2}$, A. W. Decho ${ }^{3}$ \\ ${ }^{1}$ Marine, Environmental Science, and Biotechnology Research Center, Savannah State University, Savannah, Georgia, USA \\ ${ }^{2}$ Marine Science Program, University of South Carolina, Columbia, South Carolina, USA \\ ${ }^{3}$ Department of Environmental Health Sciences, University of South Carolina, Columbia, South Carolina, USA
}

\begin{abstract}
Like many deposit-feeding organisms, the burrowing brittlestar Amphipholis gracillima feeds on particulate organic matter in surface sediments. Microbial exopolymeric secretions (EPS) are carbohydrate-enriched polymers produced by microalgae and bacteria that bind aggregates and form dense biofilms near the sediment-water interface. EPS are assimilable by some benthic infauna and may be utilized as a significant carbon source. EPS are absorbed by some deposit-feeders, including a holothurian, and may be supplemental sources of nutrition. The burrowing brittlestar A. gracillima is a deposit-feeder that was used in a mass balance approach to model the incorporation of radiolabeled EPS by bottom feeders. Brittlestars were fed ${ }^{14} \mathrm{C}$-labeled, laboratory-cultured EPS from the marine bacterium Pseudoalteromonas atlantica and a benthic diatom (Nitzschia sp.) via sediment-bound and aqueous exposures. Comparison of absorption efficiencies (AE) showed that both polymer types are highly absorbed by A. gracillima (AE = 83 to $99 \%$ ). Absorption of sedimentbound bacterial and algal EPS was similar (92.2 and 90.1\%), but bacterial EPS absorption was significantly $(\mathrm{p}<0.05)$ higher in sediment-bound $(92.2 \%)$ than aqueous $(83.3 \%)$ exposures. Algal EPS absorption was significantly higher in aqueous (99.9\%) exposures. These findings suggest that EPS may represent a significant energy source for this deposit-feeding ophiuroid and other organisms with similar feeding habits. Additionally, A. gracillima appears to be especially adept at utilizing EPS resources from benthic diatom communities.
\end{abstract}

KEY WORDS: Echinoderm $\cdot$ Extracellular polymeric secretions $\cdot$ Brittlestar $\cdot$ Deposit-feeding $\cdot$ EPS

\section{INTRODUCTION}

Extracellular polymeric secretions (EPS or exopolymers) are a class of high molecular weight exudates produced by bacteria and microalgae. For the microbes that produce them, these polysaccharide-like polymers facilitate surface attachment, help trap passing nutrients, exchange genetic material, stabilize sediments, and buffer cells against environmental stressors (Sutherland 1990, Freeman \& Locke 1995, Jahn \& Nielsen 1995, Decho 2000, De Brouwer \& Stal 2001). EPS form a structuring matrix for ubiquitous-occurring aquatic biofilms, whose biomass can far exceed that of bacterial cells (Barlocher \& Murdoch 1989, Lappin-
Scott \& Costerton 1995). Several marine bacteria produce EPS, including planktonic (Corpe 1970, Berkeley et al. 1980) and deep-sea species (Vincent et al. 1994).

This has forced us to expand modern definitions of bacterial and algal biomass to include the mass of EPS that are closely associated with cells (Goto et al. 1999). Deposit-feeding animals in marine habitats are exposed to EPS in surface films, coated particles, and marine aggregates like transparent exopolymer particles (TEP). TEP are formed from biotic (namely phytoplankton in origin) and abiotic processes like chemical precipitation (Alldrege et al. 1993, Passow 2000) and settle rapidly as marine snow (Passow et al. 1994). 
As a food source, microbial EPS have a potential impact on our understanding of benthic nutrition. Because EPS are ubiquitous in marine systems, seasonal changes in microbial productivity and population change the type of sedimentary carbohydrates available for benthic consumption (Decho 2000). For example, diatom EPS (made mostly of laminarin) on a mudflat can contain approximately $6.04 \mathrm{mg}$ of EPS $\mathrm{g}^{-1}$ of surface sediment (Underwood et al. 1995). In the low saltmarsh these concentrations can be as high as $18.37 \mathrm{mg} \mathrm{g}^{-1}$. When bacteria dominate the microbial community, EPS present are often more heteropolysaccharidic but are poorly characterized (Decho 2000, Stal 2000). Even in moderate abundances, however, EPS may have a trophic impact on smaller benthic organisms with low metabolisms. Polychaetes (Jennings \& Gelder 1976, Decho \& Lopez 1993), copepods (Decho \& Moriarty 1990), and amphipods (White \& Findlay 1988) are among the benthic macrofauna that absorb microbial EPS. EPS also bind metals (Bitton \& Friehofer 1978, Whitfield 1988, Ford \& Mitchell 1992) and displace essential metals of biological use, like calcium, in the process (Decho 1997). As pollutants become bound to biofilms, the same chargerelated processes traditionally used in wastewater treatment to concentrate toxins in wastewater sludges could also cause sediment films to become pollutantladen in sediments where benthic species live and feed.

Brittlestars are excellent representatives of the infaunal deposit-feeding community that are exposed to microbial exopolymers, although their economic and ecological importance is not easily recognized. They are scavengers and act as disposers of life and death 'by-products' and contribute to sediment turnover (Fell 1966). Through sub-lethal predation, brittlestars provide nutritional input to shrimp, crabs, and flatfish and could be an important link transferring EPS energy to higher trophic levels (Pape-Lindstrom et al. 1997). Amphipholis gracillima (Stimpson) (also Microphiopholis gracillima, Turner) belongs to the Amphiuridae family, and occurs in South Carolina (Fox \& Ruppert 1985), along the eastern shore of the United States, in the Virgin Islands, and Brazil (Thomas 1962). Using its arms and tube feet, it burrows 10 to $15 \mathrm{~cm}$ deep in subtidal sediments and feeds at the surface and below (Gielazyn et al. 1999). A. gracillima is capable of degrading some algal EPS and probably has enzymes that can hydrolyze other types of EPS found in biofilms (Hoskins et al. 2001). In this study, brittlestars were offered radiolabeled exopolymers cultured from algae and bacteria to determine whether and how efficiently the depositfeeding ophiuroid could absorb sediment-bound or aqueous exopolymers of microbial origin.

\section{MATERIALS AND METHODS}

Brittlestars were collected from Debidue Creek, a pristine mudflat in North Inlet, South Carolina $\left(37^{\circ} 20^{\prime} \mathrm{N}, 79^{\circ} 10^{\prime} \mathrm{W}\right)$. Individuals were hand-collected from sieved sediment and transported in coolers to the laboratory. Individuals were held in aquaria for approximately $1 \mathrm{mo}$ at the field conditions under which they were collected $\left(25^{\circ} \mathrm{C}\right.$, salinity $\left.=32 \mathrm{ppt}\right)$. Ground Tetramin $^{\odot}$ fish food (Tetrawerke, Germany) was fed to the brittlestars biweekly (approximately $0.03 \mathrm{mg}$ ani$\mathrm{mal}^{-1}$ ) and stopped $4 \mathrm{wk}$ prior to the feeding experiment.

Exopolymer isolation. Axenic cultures of Pseudoalteromonas atlantica (Pseudomonas atlantica; ATCC \#43666) were purchased from the American Type Culture Collection and grown for $4 \mathrm{~d}$ in Difco-enriched marine medium (25 ppt, $\mathrm{pH} 8$ ) at $25^{\circ} \mathrm{C}$ and at $100 \mathrm{rpm}$ on a shaker table. The log-phase culture was radiolabeled with $2.5 \mathrm{mCi}$ uniformly labeled ${ }^{14} \mathrm{C}$ D-glucose $\mathrm{ml}^{-1} \mathrm{cul}-$ ture and allowed to grow a further $6 \mathrm{~d}$. On Day 10, the cultures were fixed with formalin $(0.5 \%$ final concentration) and centrifuged at $10000 \mathrm{rpm} \times g$ for $20 \mathrm{~min}$. The pelleted cells were discarded. The exopolymer dissolved in the supernatant was precipitated in ethanol and resuspended in deionized water after each precipitation (Decho 1993). Precipitation was repeated 3 times, after which the polymer was redissolved and dialyzed in deionized water. Any remaining formalin residue was eliminated during the precipitation and dialysis processes. Dialysis water was changed 3 times at 8 to $12 \mathrm{~h}$ increments. Dialyzed polymer was freeze-dried and stored at $-70^{\circ} \mathrm{C}$ until use.

Non-radiolabeled Pseudoalteromonas atlantica cultures were extracted as above and sent to the Complex Carbohydrate Research Center (CCRC) at the University of Georgia (USA) for compositional analysis of EPS and to the laboratory of John Hedges in the School of Oceanography at the University of Washington (USA) for comparative analysis. Analyses were performed to determine the major sugar subunits. At the CCRC, samples were hydrolyzed using freshly prepared $1 \mathrm{M}$ methanolic- $\mathrm{HCl}$ for $16 \mathrm{~h}$ at $80^{\circ} \mathrm{C}$. Each sample was $\mathrm{N}$-acetylated using methanol, pyridine and acetic anhydride at room temperature for $6 \mathrm{~h}$. The released sugars were derivatized with Tri-Sil (Pierce Chemical) and the samples were run on a gas chromatograph using a Supelco column. Forty $\mu \mathrm{g}$ of Myo-inositol (\#15125, Sigma-Aldrich) was added as an internal standard. Dr. John Hedges performed analyses of $P$. atlantica polymer using high-pressure liquid chromatography to identify individual sugar monomers.

In order to test absorption of microalgal EPS by Amphipholis gracillima, axenic cultures of a Nitzschia species of diatom were grown for $21 \mathrm{~d}$ at $25^{\circ} \mathrm{C}$ in 
enriched F/2 media. At $3 \mathrm{wk}$, cultures were labeled with $50 \mathrm{mCi}$ uniformly labeled ${ }^{14} \mathrm{C}$ sodium bicarbonate, allowed to grow up to $60 \mathrm{~d}$, then harvested as above. Algal EPS samples were not available at the time compositional analysis was performed. However, literature supports that diatoms produce monosaccharidic EPS in the form of laminarin. Laminarin is a type $\beta$-glucuromannan composed of glucuronic acid and mannose.

Absorption experiments. Treatments were: bacterial exopolymer bound to sediment (sediment-bound), bacterial exopolymer dissolved in seawater (aqueous), algal exopolymer bound to sediment, and algal exopolymer dissolved in seawater. Brittlestars were offered $0.5 \mathrm{~g}$ of sediment food mixtures containing radiolabeled bacterial or algal EPS bound to untreated sediment from the brittlestar collection site and Tetramin ${ }^{\odot}$ fish food (3.086 mg animal ${ }^{-1}$ ). Fish food was added to increase palatability. Brittlestars in aqueous treatments received $100 \mu \mathrm{l}$ of food solution prepared by dissolving bacterial or algal EPS in filtered, autoclaved seawater. Before food mixtures were prepared, the activity of a subsample of each polymer type was measured using a Packard Tri Carb liquid scintillation counter (LSC, Hewlett Packard, model \#2100TR/2300TR) in disintegrations per minute (dpm). Algal polymer had an activ-

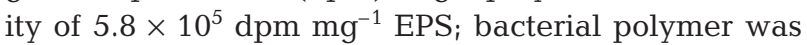
$5.43 \times 10^{3} \mathrm{dpm} \mathrm{mg}^{-1}$ EPS. Food mixtures for treatments using sediment-bound algal polymer were mixed with sediment to a final activity of $2.917 \times 10^{5} \mathrm{dpm} \mathrm{g}^{-1}$ food mixture. Sediment-bound bacterial EPS treatments had a final concentration of $2.07 \times 10^{4} \mathrm{dpm} \mathrm{g}^{-1}$ food mixture. Final aqueous activities were $2.54 \times 10^{-4}$ and $1.4 \times 10^{-3} \mathrm{dpm} \mathrm{ml} \mathrm{m}^{-1}$ for the algal and bacterial exposures, respectively. Individual brittlestars were randomly assigned to each treatment $(n=10)$ using a standard table of random digits (Moore \& McCabe 1989). Each was placed in a $6.35 \mathrm{~cm}$ diameter culture dish (Carolina Biological Supply, \#BA-74-1000) filled with $10 \mathrm{ml}$ seawater and allowed to acclimate in the dark for $12 \mathrm{~h}$. All seawater used in this study was filtered on a 0.45 micron Supor-450 membrane (Gelman Sciences, P/N 60173) and a Whatman GF/C filter (VWR Scientific Products \#28497-685) and then autoclaved to reduce bacterial activity. Approximately $0.5 \mathrm{~g}$ of food mixture was placed in each dish for the sedimentbound EPS treatments. For dissolved treatments, the sediment was replaced with a $1 \mathrm{ml}$ aliquot of EPS solution containing the appropriate exopolymer. All animals were fed at the same time and in darkness for $12 \mathrm{~h}$. After feeding, brittlestars were removed from dishes, rinsed with seawater and placed in $10 \mathrm{ml}$ vials with fresh seawater for $24 \mathrm{~h}$. This $24 \mathrm{~h}$ 'cold' incubation (with no food mixture) allowed animals to digest or egest the food they had ingested and represented the gut evacuation period. Afterwards, animals were rinsed again and the disc cover was removed. The stomach was flushed with seawater to insure that undigested food was not included in tissue activity measurements. Material expelled during the cold evacuation period and this gut rinse was included in the measure of egesta as gut contents. Brittlestars were dissected into 2 body fractions: the disc cover and the oral frame and arms. Each fraction was suspended in $1 \mathrm{ml}$ seawater and digested separately with $2 \mathrm{ml}$ Scintigest (Fisher Scientific, \#SO-X-10) at $100^{\circ} \mathrm{C}$ until tissue was completely solubilized. All samples were suspended in Scintisafe Econo I liquid scintillation cocktail (\#SX20-5, Fisher Scientific Products). Activity (in dpm) was measured with the LSC.

Respiration measurements. The amount of ${ }^{14} \mathrm{C}$ lost due to respiration was estimated by feeding 4 brittlestars radiolabeled EPS of each polymer type in the same manner as in the sediment-bound treatment. The cold incubation technique was modified to measure $\mathrm{CO}_{2}$ release. After feeding, these brittlestars were placed in a $500 \mathrm{ml}$ syringe bottle in $10 \mathrm{ml}$ seawater. A suspended basket was fashioned from the bulb of a transfer pipette and nested with a folded piece of filter paper. After $24 \mathrm{~h}, 2 \mathrm{ml}$ of $\mathrm{H}_{2} \mathrm{SO}_{4}$ was added to kill the brittlestar and release dissolved carbon dioxide from the water. The filter paper was saturated with $1 \% \mathrm{w} / \mathrm{v}$ $\mathrm{KOH}$ and the bottle was agitated at $50 \mathrm{rpm}$ for $2 \mathrm{~h}$ so the released ${ }^{14} \mathrm{CO}_{2}$ would absorb into the filter paper. The paper was then suspended in cocktail and read in the LSC. The respiration activity (in dpm) was included in measurements of loss in absorption efficiency calculations. Respiration activities were also converted to micrograms of carbon (from $\mathrm{CO}_{2}$ ) based on the activity of the polymer used for each treatment. This calculation was performed for each individual and represented carbon lost via ${ }^{14} \mathrm{CO}_{2}$ by each brittlestar over $24 \mathrm{~h}$. Respiration rates were calculated and expressed in units of $\mathrm{mg} \mathrm{C}$ ind. ${ }^{-1} \mathrm{~h}^{-1}$.

Absorption calculations. Amphipholis gracillima has a mouth that leads into an esophagus and a blind stomach (Pentreath 1969). Because of its incomplete digestive tract, typical mass balance equations that gauge uptake by fecal evacuation of label could not be used for this brittlestar. Unutilized food is expelled as egesta, making it necessary to modify a tissue/fecesbased equation to accommodate the waste produced by this deposit-feeder. Absorption efficiency was defined as the percentage of radioactive label absorbed by the brittlestar divided by the total uptake. It was calculated based upon the amount of radiolabel absorbed and egested by the animal (Decho 1993):

$$
\begin{aligned}
& \% \text { absorption efficiency }(A E)= \\
& {\left[1-\left({ }^{14} C \text { egestion: }:{ }^{14} C \text { ingestion }\right)\right] \times 100}
\end{aligned}
$$


The values obtained from the cold incubation and the subsequent rinse were combined to represent gut contents expelled by the brittlestar (egestion). During dissection, the gut contents were flushed before brittlestars were read in the LSC. Though very little material was obtained, it was also viewed as unprocessed food and treated as egesta. Total ingestion was estimated by summing the egestion and the radioactivity of each brittlestar at the end of the experiment. The absorption efficiency reflected uptake of radiolabeled carbon that had been incorporated into tissues. It was corrected for background radioactivity values measured in animals fed unlabeled food, and for unused food in the gut. Background values were attributed to natural fluorescence and not radiolabel. The imposed $12 \mathrm{~h}$ feeding period affected the absorption efficiency calculation by making it time-dependent since feeding was artificially ceased and not naturally ended by the brittlestar. However, no feeding activity was observed at $12 \mathrm{~h}$. This time-dependent absorption efficiency was the final datum of interest and was used for statistical comparisons between treatment groups. Absorption efficiencies were assessed and compared using normality tests and an ANOVA using polymer type and exposure as single factors. Two-factor analysis was eliminated due to interaction between the factors. All statistical analyses were performed using Statistical Analysis System software (SAS Institute).

Partitioning between the disc cover, oral frame and arms. Because the majority of the metabolically active tissue in Amphipholis gracillima is in the oral frame and arms, comparisons made between the incorporation of EPS into the 2 body sections were made proportional by adjusting the radioactivity measurements in each section by its respective tissue mass. The radioactivities of disc tissues and those in the arms and oral frame were divided by the mean ash-free dry weight (AFDW) of the tissue $($ disc $=2.33 \mathrm{mg}$ mean AFDW ; oral frame and arms = 35.38 mg mean AFDW; Dobson et al. 1991).

\section{RESULTS}

Analyses by the CCRC indicated that the exopolymer of Pseudoalteromonas atlantica consisted of $70 \mathrm{~mol} \%$ glucose (Table 1) and $72 \%$ total carbohydrate. The remaining sugars (in rank order) were mannose, galactose, galacturonic acid and glucuronic acid. Independent analyses by Dr. John Hedges at the University of Washington showed similar composition, $74 \%$ glucose. Mannose composition was higher (14\%) and galactose only slightly lower (9\%). Hedges‘ analyses did not include uronic acids or total carbohydrate percentage, but trace analyses for arabinose, fucose, ribose, and rhamnose revealed $<1 \%$ of each monomer.
Amphipholis gracillima absorbed both algal and bacterial polymer with high efficiency, with very little carbon loss due to respiration (Table 2). Loss of ${ }^{14} \mathrm{C}$ ranged 0.02 to $0.08 \mu \mathrm{g}{ }^{14} \mathrm{C}$ ind. ${ }^{-1}$ over $24 \mathrm{~h}$ (Table 3 ). These losses were equivalent to less than $1 / 10$ of a percent of the total body carbon of animals fed algal EPS and less than 1/1000 that of brittlestars fed bacterial EPS. In aqueous- or sediment-bound form EPS was taken up by brittlestars with $83 \%$ or higher efficiency (Table 2). Analysis of the $\log _{10}$-transformed absorption efficiencies showed no evidence against normality via a Wilk-Shapiro test $(\mathrm{p}=0.1704$; Shapiro $\&$ Wilk 1965). Normality plots were linear and residual plots were homoscedastic. When brittlestars fed bacterial exopolymer were compared across exposures, animals that received sediment-bound polymer utilized it more efficiently $(92.2 \%)$ than those exposed to the same polymer in aqueous form $(83.3 \%, 2$-sided $\mathrm{p}=0.0364 ;$ Table 2). While sediment-bound algal polymer was absorbed with an efficiency of (90.1\%) and was similar to that of sediment-bound bacterial polymer $(92.2 \%)$, the aqueous algal polymer was absorbed much more effectively than the bound form (>99.9\%, 2-sided p =0.0005; Table 2).

Calculations evaluating the total ${ }^{14} \mathrm{C}$ incorporated into the disc cover versus the oral frame and arms showed that brittlestars given EPS in sediment form absorbed almost all the EPS into the disc cover (Fig. 1). In both bacterial aqueous and sediment-bound treatments the radiolabel accumulated in the disc was an order of magnitude greater than that in the oral frame and arms. This was also true for the aqueous algal treatment. Disc concentra-

Table 1. Carbohydrate composition of Pseudoalteromonas atlantica exopolymer determined by 2 independent analytical laboratories and methods. CCRC $=$ Complex Carbohydrate Research Center at the University of Georgia (USA). UW = Dr. John Hedges, University of Washington School of Oceanography. -: analysis was not performed

\begin{tabular}{|lcc|}
\hline & \multicolumn{2}{c|}{ Mole \% } \\
Sugar & CCRC & UW \\
\hline Mannose & 9.8 & 14.28 \\
Galactose & 9.1 & 8.81 \\
Glucose & 70.3 & 74.17 \\
Galacturonic acid & 6.5 & - \\
Glucuronic acid & 4.0 & - \\
Arabinose & - & 0.28 \\
Ribose & - & 0.70 \\
Xylose & - & 0.33 \\
Fucose & - & 1.21 \\
Rhamnose & - & 0.73 \\
Total accounted for & 99.7 & 100.51 \\
\% carbohydrate & $72 \%$ & \\
\hline
\end{tabular}


Table 2. Absorption efficiencies (AE) of Amphipholis gracillima fed bacterial and algal exopolymer in aqueous and particulate form (mean $\pm \mathrm{SE}$ ). Statistical differences are indicated by asterisks (alpha $=0.05$ ). ${ }^{*}=$ EPS AE differed between exposures; ${ }^{* *}=\mathrm{AE}$ of dissolved EPS differed between polymer types

\begin{tabular}{|lcc|}
\hline \multirow{2}{*}{ Exposure } & \multicolumn{2}{c|}{ Polymer type } \\
& $\begin{array}{c}\text { Pseudoalteromonas } \\
\text { atlantica EPS }\end{array}$ & Nitzschia EPS * \\
\hline Sediment-bound & $92.2+1.86$ & $90.1+1.15$ \\
Dissolved $^{* *}$ & $83.3+3.49$ & $>99.9+3.62$ \\
\hline
\end{tabular}

tions of ${ }^{14} \mathrm{C}$ in brittlestars fed sediment-bound algal EPS were much higher than oral frame and arm levels.

\section{DISCUSSION}

\section{EPS availability}

Amphipholis gracillima clearly has the ability to absorb secreted algal and bacterial extracellular polymeric secretions. Compositional analyses of bacterial polymers demonstrated that they represent an energy source that can be efficiently used by this animal. Ophiuroids have seasonal and opportunistic feeding habits - they may scavenge, feed on particles or be carnivorous (Dearborn \& Edwards 1982, Hendler 1982). In South Carolina, their feeding activity is highest between February and November, when temperatures are rising and organic production increases. Although A. gracillima has been described primarily as an indiscriminant surface deposit-feeder, omnivore, and scavenger (Singletary 1970), high algal exopolymer absorption efficiencies are appropriate given the ecology of the mudflat this species lives in. Such high absorption efficiencies also make a plausible connection between high seasonal benthic diatom production and the feeding behavior of the brittlestar. Through its ability to absorb both algal and bacterial EPS, $A$. gracillima could capitalize on each carbon source during its time of abundance. Cammen (1980) observed a similar seasonal dynamic when he calculated a partial monthly carbon budget for the deposit-feeding polychaete Nereis succinea. In the fall and winter months, bacteria contributed more to the carbon requirement of the polychaete ( 7 to $10 \%$ ) than microalgae ( 2 to $8 \%$ ). In the warmer months, the algal contribution increased to 7 to $10 \%$ as well, diminishing to lower values with the end of the warm season. In other environments, microalgal biomass can be an order of magnitude higher than bacterial biomass in surface sediment
Table 3. Carbon loss by respiration of Amphipholis gracillima fed sediment-bound bacterial and algal EPS. Values are expressed as micrograms of carbon respired as carbon dioxide by brittlestars over $24 \mathrm{~h}$. Carbon was converted from ${ }^{14} \mathrm{C}$ measured in disintegrations per minute $(\mathrm{dpm})$

\begin{tabular}{|ccc|}
\hline Individual & Bacterial EPS & Algal EPS \\
\hline 1 & 0.0537 & 14.64 \\
2 & 0.774 & 3.82 \\
3 & 0.0198 & 1.99 \\
4 & lost & 18.45 \\
Mean & $0.025 \pm 0.01$ & $4.86 \pm 2.02$ \\
\hline
\end{tabular}

(Rublee 1982) and can account for over $70 \%$ of the organic carbon in some size fractions of the sediment (Cammen 1980). Such an opportunistic absorption strategy would make sense for other members of the benthos like bivalves (Decho \& Luoma 1996) and polychaetes that may also need flexible dietary strategies in order to survive.

In comparison with the abundance of EPS found in natural biofilms, EPS additions provided in this study are conservative and much lower than the levels benthic invertebrates may typically encounter in their natural habitat. Using extraction methods similar to those in this study, Underwood et al. (1995) analyzed marine intertidal sediments for soluble (hydrophilic, labile) and capsular (EDTA-extractable) EPS. They found 4.78 to $10.94 \mathrm{mg}$ total EPS $\mathrm{g}^{-1}$ sediment in samples from different areas of the saltmarsh. Total diatom EPS abundance was approximately $6.04 \mathrm{mg} \mathrm{g}^{-1}$ sediment in mudflat samples where the microbial community was dominated by diatom films. Soluble diatom EPS like that used in this study accounted for $1.64 \pm 0.9 \mathrm{mg} \mathrm{g}^{-1}$ sediment in these films. Upper saltmarsh samples in which filamentous bacteria made up $50 \%$ of the microbial community had $10.94 \mathrm{mg} \mathrm{g}^{-1}$ sediment. Samples from a cyanobacterial mat yielded roughly half that amount. Relative to the sediment abundance of EPS measured by Underwood et al. (1995), Amphipholis gracillima may be exposed to $0.82 \mathrm{mg} \mathrm{g}^{-1}$ sediment diatom EPS in the natural environment, more than the 0.255 to $0.577 \mathrm{mg}$ algal EPS that brittlestars received in this study. Therefore, it is possible that A. gracillima and other deposit-feeders have twice the EPS abundance available to them in natural sediments than was present in this study. In some environments, EPS abundance may be 3 to 6 times as high. If volumes of this magnitude are coupled with absorption efficiencies greater than $90 \%$, there is great potential for substantial microbe-macrofauna energy transfer and more evidence that microbial constituents may significantly support some sediment communities. Although bacteria coated with capsule polymers are differentially 


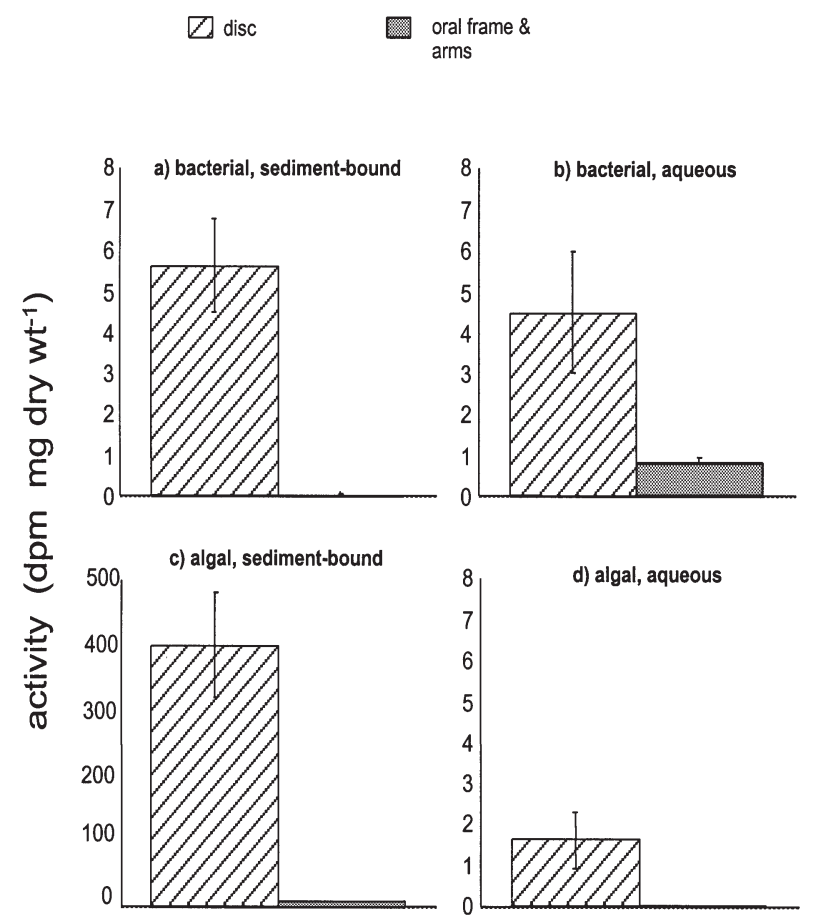

Fig. 1. Partitioning of ${ }^{14} \mathrm{C}$-labeled exopolymer in the disc, oral frame and arm tissues of Amphipholis gracillima. Values represent true absorption in each body section (mean dpm $\pm \mathrm{SE}$, $\mathrm{n}=11$ ). Absorption values were divided by the mean tissue mass $($ disc $=2.33 \mathrm{mg}$, oral frame and arms $=35.38 \mathrm{mg}$ ) from Dobson et al. (1991)

digested by deposit-feeders and some EPS are more degradable by gut enzymes than others (Plante \& Shriver 1998, Plante 2000), this research supports the idea that some sediment communities may be significantly supported by their microbial constituents (Plante et al. 1990).

\section{Energy gain}

The carbon needs of Amphipholis gracillima may be largely satisfied by the cellular and polymeric components of microbial films because, unlike other depositfeeders with greater energy requirements, brittlestars have less metabolically active tissue compared to other benthic invertebrates of similar size. The typical echinoderm skeleton forms more than $50 \%$ of the dry weight of the organism and is greater than $71 \%$ for most ophiuroids (Emson 1984). Since the skeleton of A. gracillima comprises 58 to $71 \%$ of its total weight (Dobson et al. 1991, Stancyk et al. 1994) it should have reduced energetic costs compared to organisms with a greater amount of metabolically active tissue (Lawrence 1987, Clements et al. 1988). Ophiuroid oxygen uptake rates are lowest of the 4 echinoderm classes. Carbon loss measured in this investigation was low, as are literature values for oxygen use in this species (Clements et al. 1988). If we use respiration as a gauge for energetic demand, our uptake data suggest that brittlestars are able to effectively exploit EPS, which, from the energetic perspective of the brittlestar, are a rich resource.

Brittlestars absorbed 83 to $99 \%$ of the 0.127 to $2.295 \mathrm{mg}$ polymer they received in the sediment food mixture. Amphipholis gracillima received approximately 0.988 to $24.18 \mu \mathrm{g}$ carbon from EPS in $12 \mathrm{~h}$ and respired 0.0198 to $18.45 \mu \mathrm{g}$ carbon in the form of ${ }^{14} \mathrm{CO}_{2}$ over the $24 \mathrm{~h}$ cold incubation period. These outcomes indicate that brittlestars are able to utilize microbial EPS efficiently, regardless of type or form.

Although energy budgets have not been constructed for Amphipholis gracillima, the mean individual has an ash-free dry weight of $52.47 \mathrm{mg}$ and an estimated caloric content of $0.93 \mathrm{kcal} \mathrm{g}^{-1}$ dry weight (Dobson et al. 1991). Based on these values, the average specimen of A. gracillima has a total body energy content of 355.2 J. Numerical densities of amphiurids in the Mediterranean Sea (Amphiura angulari and Amphiura antarctica) and in the South Indian Sea (Amphiura chiajei and Amphiura filiformis) represent 15.9 to $46.8 \mathrm{~kJ} \mathrm{~m}^{-2}$ (Lawrence \& Guille 1982). Thirty A. gracillima in a square meter in North Inlet, South Carolina, have a standing crop of approximately $10.66 \mathrm{~kJ}$. Since amphiurids are regularly exposed to repeated sublethal predation (Pape-Lindstrom et al. 1997) and rapidly regrow lost tissue (Stancyk et al. 1994), they represent a renewable energy source for their predators, and one that is probably supported by sedimentary carbon sources like microbial EPS. In the SE United States, A. gracillima is abundant in muddy environments and is commonly preyed upon by shrimps and crabs. Our data indicate that brittlestars could be important not only to nutrient cycling, but also to energy transfer to commercially important species.

\section{Role of EPS exposure}

Amphipholis gracillima accumulated more of the carbon label in the disc cover than in the oral frame and arms most likely because digestion and absorption across the gut wall was still taking place. Baird \& Thistle (1986) found a similar short-term concentration of radiolabeled Pseudoalteromonas atlantica polymer in the hemal vessels associated with the intestine of a holothurian.

The form of exposure affected both bacterial and algal polymer utilization. Brittlestars absorbed aque- 
ous algal polymer much better than aqueous bacterial polymer, with the highest absorption efficiency of all treatments (>99.9\%, Table 2). Utilizing non-particulate EPS is important for an animal with regenerative capabilities like Amphipholis gracillima. When threatened, brittlestars may 'autotomize' or cast away the arms or central disk cover (including the gut). For regenerating brittlestars that have lost their disc cover or for other soft-bodied invertebrates that regenerate, resorption and dissolved uptake are the primary form of sustenance. Fielman et al. (1991) showed that regenerating brittlestars directly store and consume energy to replacement tissues until the animal develops to what is considered its 'minimal functional configuration'3 arms and a disc with a gut capable of processing food. It takes 8 to $14 \mathrm{~d}$ for $A$. gracillima to regenerate a functioning gut (Dobson 1986). Until then, the brittlestar takes up dissolved nutrients such as amino acids or resorbs stored nutrients, using these resources to regenerate lost tissues (Clements et al. 1988). High absorption efficiencies in the aqueous uptake treatments of both polymers support the contention that brittlestars are probably effective consumers of dissolved organics, especially during regeneration.

The ubiquity of bacterial biofilms in marine sediments makes it likely that brittlestars are exposed to particles with EPS bound to them. A typical biofilm in muddy sediment is most distinct on the surface, where diatoms and other phototrophs generate EPS (Decho 2000). Deposit-feeders foraging at the sediment-water interface disrupt microbial films as they burrow and feed. As an indiscriminate particle feeder, Amphipholis gracillima most likely consumes sediment-bound EPS in this manner and in amounts greater than those provided to the animals in this study.

\section{Mechanisms of dissolved material uptake}

Symbiotic bacteria often aid animals in the acquisition of nutrients and are normally considered as being associated with the gut. However, several species of echinoderms, including 10 ophiuroids, have subcuticular bacteria living under the epidermis (Kelly \& McKenzie 1995). Although no ecological role has been identified for these bacteria, their presence has implications for feeding across developmental stages, uptake of dissolved organic material and recognition of antigens (Kelly \& McKenzie 1995). A portion of the dissolved EPS accumulated by Amphipholis gracillima could be attributable to endosymbionts. However, in experiments conducted to measure the contribution of subcuticular bacteria to dissolved nutrient uptake, Lesser \& Walker (1992) showed that only $1 \%$ of the total dissolved amino acids taken up by the ophiuroid
Amphipholis squamata could be attributed to its subcuticular bacteria. We considered the role of subcuticular and gut bacteria to be minimal, so no effort was made in this study to separate their uptake of radiolabel from that of the brittlestar.

This is the second study to demonstrate the utilization of microbial EPS by an echinoderm since EPS uptake was demonstrated in a holothurian (Baird \& Thistle 1986). Amphipholis gracillima is the first ophiuroid shown to incorporate microbial EPS into its tissues. These results support the hypothesis that microbial EPS may contribute significantly to the energetic needs of infaunal ophiuroids. Additionally, the pronounced absorption of algal and bacterial EPS shown here illustrates a short pathway for microbial exudates to be utilized by higher trophic levels and indirectly by their predators. The results suggest that microbial exopolymers may represent an important nutritional component in benthic ecosystems.

Acknowledgements. This research was supported in part by the Slocum-Lunz Foundation, the University of South Carolina School of the Environment, the National Oceanographic and Atmospheric Administration, and the Center for Plant and Microbial Complex Carbohydrates (Department of Energy DE-FG09-93ER-20097). Sincere thanks go to Dr. John Hedges and his laboratory at the University of Washington School of Oceanography for analyzing EPS samples and for help with data interpretation. This work would not have been possible without the support of the Belle W. Baruch Institute, the Marine Science and Environmental Science Programs at USC. Special thanks to Dr. Alan Lewitus for providing samples of the Nitzschia diatom isolate, to Drs. V. Pernell Lewis and Christian Schlekat, Banu Varlik, and Adam Hoyt for laboratory assistance and to 2 anonymous reviewers for their valuable comments. This is contribution no. 1242 of the Belle W. Baruch Institute for Marine Biology and Coastal Research.

\section{LITERATURE CITED}

Alldredge AL, Passow U, Logan B (1993). The existence, abundance, and significance of large transparent exopolymer particles in the ocean. Deep Sea Res I 40:1131-1140

Baird BH, Thistle D (1986) Uptake of bacterial extracellular polymer by a deposit-feeding holothurian (Isostichopus badionotus). Mar Biol 92:183-187

Barlocher F, Murdoch JH (1989) Hyporheic biofilms-a potential food source for interstitial animals. Hydrobiologia 184:61-67

Berkeley RLW, Lynch JM, Melling J, Rutter PR, Vincent B (eds) (1980) Polysaccharides in the adhesion of marine and freshwater bacteria. In: (eds) Microbial adhesion to surfaces. Ellis Horwood, Chichester, p 329-338

Bitton G, Friehofer V (1978) Influence of extracellular polysaccharides on the toxicity of copper and cadmium toward Klebsiella aerogenes. Microb Ecol 4:119-125

Cammen LM (1980) The significance of microbial carbon in the nutrition of the deposit feeding polychaete Nereis succinea. Mar Biol 61:9-20

Clements LAJ, Fielman KT, Stancyk SE (1988) Regeneration 
by an amphiurid brittlestar exposed to different concentrations of dissolved organic material. J Exp Mar Biol Ecol 122:47-61

Corpe WA (1970) An acid polysaccharide produced by a primary film forming bacteria. Develop Ind Microbiol 11: $402-412$

Dearborn JH, Edwards KC (1982) Analysis of data on the feeding biology of Antarctic sea stars and brittlestars. Antarctic J of the US 19(5):138-139

De Brouwer JFC, Stal LJ (2001) Short-term dynamics in microphytobenthos distribution and associated extracellular carbohydrates in surface sediments of an intertidal mudflat. Mar Ecol Prog Ser 218:33-44

Decho AW (1993) Methods for the observation and use in feeding experiments of microbial exopolymers. In: Kemp PF, Sherr BF, Sherr EB, Cole JJ (eds) Handbook of methods in aquatic microbial ecology. Lewis Publishers, Ann Arbor, MI, p 685-694

Decho AW (1997) Microbial biotransformations of metals: effects on altering the trophic availability of metals. In: Vernberg FJ, Vernberg WJ, Siewicki T (eds) Sustainable development in the southeastern coastal zone. Belle W. Baruch Library in Marine Science 20. Univ of South Carolina Press, Columbia, p 265-284

Decho AW (2000) Microbial biofilms in intertidal systems: an overview. Cont Shelf Res 20:1257-1273

Decho AW, Lopez GR (1993) Exopolymer microenvironments of microbial flora: multiple and interactive effects on trophic relationships. Limnol Oceanogr 38(8):1633-1645

Decho AW, Luoma SN (1996) Flexible digestion strategies and trace metal assimilation in marine bivalves. Limnol Oceanogr 41(3):568-572

Decho AW, Moriarty DJW (1990) Bacterial exopolymer utilization by a harpacticoid copepod: a methodology and results. Limnol Oceanogr 35(5):1039-1049

Dobson WE, Stancyk SE, Clements LA, Showman RM (1991) Nutrient translocation during early disc regeneration in the brittlestar Microphiopholis gracillima (Stimpson) (Echinodermata: Ophiuroidea). Biol Bull 180:167-184

Emson RH (1984) Bone idle-a recipe for success? In: Keegan BF, O'Connor BDS (eds) Echinodermata Proc 5th Int Conf, Galway. Balkema, Rotterdam, p 25-30

Fell HB (1966) The ecology of ophiuroids. In: Boolootian R (ed) The physiology of the Echinodermata. Interscience Publishers, New York, p 87-128

Fielman KT, Stancyk SE, Dobson WE, Clements LAJ (1991) Effects of disc and arm loss on regeneration by Microphiopholis gracillima (Echinodermata: Ophiuroidea) in nutrient-free seawater. Mar Biol 111:121-127

Ford T, Mitchell R (1992) Microbial transformations of toxic metals. In: Mitchell R (ed) Environmental microbiology. John Wiley \& Sons, New York, p 83-101

Fox RS, Ruppert EE (1985) Shallow-water marine benthic macroinvertebrates of South Carolina. Univ of S Carolina Press, Columbia

Freeman C, Locke MA (1995) The biofilm polysaccharide matrix: a buffer against changing organic substrate supply. Limnol Oceanogr 40(2):273-278

Gielazyn M, Stancyk SE, Piegorsch WW (1999) Experimental evidence of subsurface feeding by the burrowing ophiuroid Amphipholis gracillima (Hendler) (Echinodermata). Mar Ecol Prog Ser 184:129-138

Goto N, Kamawura T, Mitamura O, Terai H (1999) Importance of extracellular organic carbon production in the total primary production by tidal flat diatoms in comparison to phytoplankton. Mar Ecol Prog Ser 190:289-295

Hendler G (1982) The feeding biology of Ophioderma bre- vispinum (Ophiuroidea: Echinodermata). In: Lawrence JM (ed) Echinoderms: Proc Int Conf, Tampa Bay, Balkema, Rotterdam, p 21-27

Hendler G, Miller JE, Pawson DL, Kier PM (1995) Sea stars, sea urchins, and their allies: echinoderms of Florida and the Caribbean. Smithsonian Institution Press, Washington, DC

Hoagland KD, Rosowski JR, Gretz MR, Roemer SC (1993) Diatom extracellular polymeric substances: function, fine structure, chemistry, and physiology. J Phycol 29:537-566

Hoskins DL, Stancyk SE, Decho AW, Lewis VP, Baynes J (2001) Digestion of biofilm carbohydrates by the depositfeeding brittlestar Amphipholis gracillima (Stimpson) (Ophiuroidea: Amphiuridae). In: Barker MF (ed) Echinoderms. Proc Int Conf, Dunedin, New Zealand, Balkema, Rotterdam

Jahn A, Nielsen PH (1995) Extraction of extracellular polymeric substances from biofilms using a cation exchange resin. Wat Sci Tech 32(8):157-164

Jennings JB, Gelder SR (1976) Observations on the feeding mechanism, diet, and digestive physiology of Histriobdella homari van Beneden 1858: an aberrant polychaete symbiotic with North American and European lobsters. Biol Bull 151:489-517

Kelly MS, McKenzie JD (1995) Survey of the occurrence and morphology of subcuticular bacteria in shelf echinoderms from the north-east Atlantic Ocean. Mar Biol 123:741-756

Lappin-Scott HM, Costerton JW (1995) Microbial biofilms. Cambridge Univ Press, Cambridge

Lawrence JM (1987) Echinodermata. In: Vernberg FJ, Pandian TJ (eds) Animal Energetics, Vol 2. Academic Press, New York, p 229-321

Lawrence JM, Guille A (1982) Organic composition of tropical, polar, and temperature water echinoderms. In: Lawrence JM (ed) Echinoderms: Proc Int Conf, Tampa Bay. Balkema, Rotterdam, p 313-317

Lesser MP, Walker CW (1992) Comparative study of the uptake of dissolved amino acids in sympatric brittle stars with and without endosymbiotic bacteria. Comp Biochem Physiol 101B(1/2):217-223

Moore DS, McCabe GP (1989) Introduction to the practice of statistics. WH Freeman, New York

Pape-Lindstrom PA, Feller RJ, Stancyk SE, Woodin SA (1997) Sublethal predation: field measurements of arm tissue loss from the ophiuroid Microphiopholis gracillima and immunochemical identification of its predators in North Inlet, South Carolina, USA. Mar Ecol Prog Ser 156: $131-140$

Passow U (2000) Formation of transparent exopolymer particles, TEP, from dissolved precursor material. Mar Ecol Prog Ser 192:1-11

Pentreath RJ (1969) The morphology of the gut and a qualitative review of digestive enzymes in some New England ophiuroids. J Zool (Lond) 159:413-423

Plante C (2000) Role of bacterial exopolymeric capsules in protection from deposit feeder ingestion. Aquat Microb Ecol 21:211-219

Plante CJ, Schriver AG (1998) Differential lysis of sedimentary bacteria by Arenicola marina L.: Examination of cell wall structure and exopolymeric capsules as correlates. J Exp Mar Biol Ecol 229:35-52

Plante CJ, Jumars PA, Baross JA (1990) Digestive associations between marine detritivores and bacteria. Annu Rev Ecol Syst 21:29-44

Rublee PA (1982) Seasonal distribution of bacteria in salt marsh sediments in North Carolina. Estuar Coast Shelf Sci 15(1):67-74 
Shapiro SS, Wilk MB (1965) An analysis of variance test for normality (complete samples). Biometrika 52:591-611

Singletary R (1970) The biology and ecology of Amphioplus coniortodes, Ophionepthys limicola, and Micropholis gracillima (Ophiuroidea: Amphiuridae) Carib J Sci 16(1-4): $39-55$

Stal LJ (2000) The ecology of cyanobacteria. Kluwer Academic Publishers, Dordrecht

Stancyk SE, Golde HM, Pape-Lindstrom PA, Dobson WE (1994) Born to Lose. I. Measures of tissue loss and regeneration by the brittlestar Microphiopholis gracillima (Echinodermata: Ophiuroidea). Mar Biol 118:451-462

Sutherland IW (1990) Biotechnology of microbial exopolysaccharides. Cambridge Univ Press, New York

Thomas LP (1962) The shallow water amphiurid brittlestars

Editorial responsibility: John Lawrence (Contributing Editor), Tampa, Florida, USA
(Echinodermata: Ophiuroidea) of Florida. Bul Mar Sci Gulf Carib 12:623-694

Underwood GJC, Paterson DH, Parkes RS (1995) The measurement of microbial carbohydrates exopolymers from intertidal sediments. Limnol Oceanogr 40(7):1243-1253

Vincent P, Pignet P, Talmont F, Bozzi L, Fournet B, Guezennec J, Jeanthon C, Prieur D (1994) Production and characterization of an exopolysaccharide excreted by a deep-sea hydrothermal vent bacterium isolated from the polychaete annelid Alvinella pompejana. Appl Env Micr 60(11): 4134-4144

White DC, Findlay RH (1988) Biochemical markers for measurement of predation effects on the biomass, community structure, nutritional status, and metabolic activity of microbial biofilms. Hydrobiologia 159:119-132

Submitted: October 12, 2001; Accepted: September 3, 2002 Proofs received from author(s): December 23, 2002 